\title{
Construction techniques of domes in some Ottoman baths
}

\author{
Kader Reyhan ${ }^{\mathrm{a}, *}$, Başak İpekoğlu ${ }^{\mathrm{b}, 1}$, Hasan Böke ${ }^{\mathrm{b}, 2}$ \\ a Department of Architecture, Faculty of Architecture, Izmir Institute of Technology, 35430 Izmir, Turkey \\ ${ }^{\mathrm{b}}$ Department of Architectural Restoration, Faculty of Architecture, Izmir Institute of Technology, 35430 Izmir, Turkey
}

\section{A R T I C L E I N F O}

\section{Article history:}

Received 31 October 2012

Accepted 6 November 2012

Available online 8 February 2013

\section{Keywords:}

Ottoman bath

Dome

Construction technique

Bond type

Oculi

\begin{abstract}
A B S T R A C T
In Ottoman bath architecture, the dome is the spherical structural component covering the square planned dressing hall, warm and hot spaces. In this study, the relationship between bond type, dome span, dome height, dome thickness, and the number of oculi of domes in some Ottoman baths located in Western Anatolia (Turkey) were investigated for the purpose of evaluating construction techniques and architectural characteristics. The studied domes were constructed with brick and lime mortar as binder. In the construction of domes, whole and half bricks with different dimensions were used. In all domes, the surfaces were covered with brick-lime plaster, a thin layer on the interior and a thick layer on the exterior. Terracotta pipes placed in the brick bond or the openings made through the brick bond constituted oculi for lighting. Depending on the brick bond, a linear relationship was determined between the span, height, and number of oculi, whereas a mathematical ratio between $1: 10$ and 1:12 was determined between the span and thickness of the domes. It has also been noted that as the dome span increases, so does the height, thickness at the springing level and the number of oculi. The domes examined with these properties should be seen as historical documents representing the construction technology of the 15 th century. Therefore, these properties of domes must be preserved and special care needs to be taken as not to lose the original qualities of these domes during conservation works.
\end{abstract}

(C) 2013 Elsevier Masson SAS. All rights reserved.

\section{Introduction}

A dome, in a hemispherical form in terms of morphology, is a curvilinear superstructure. Domes have been effectively used to cover the circular, square, hexagonal, and octagonal planned spaces in historic buildings since the Roman period. A dome, which enables covering spatial components with long span and large volumes without supporting elements in the middle in masonry structures, is a structural element widely built of brick and lime mortar as binder. Moreover, domes provided both dynamic mass order on the exterior and striking optical effects in the interior spatial perception for special spaces and units.

In the magnificent monumental structures built in Roman, Byzantine, Seljuk, Ottoman, Renaissance, and Baroque periods, it is obvious that the dome had a special place both in building and environmental scale. The Pantheon in Rome (126 AD), HagiaSophia in İstanbul (first completed in 537, rebuilt in 563 after earthquake), Florence Cathedral in Florence (1436), Sulaimaniya

\footnotetext{
* Corresponding author. Tel.: +90 533238 1156; fax: +90 2327507012 . E-mail addresses: kaderreyhan@gmail.com (K. Reyhan), basakipekoglu@iyte.edu.tr (B. İpekoğlu), hasanboke@iyte.edu.tr (H. Böke).

${ }^{1}$ Tel.: +90 232750 7075; fax: +90 2327507012 .

2 Tel.: +90 232750 7035; fax: +90 2327507012 .
}

Mosque in İstanbul (1557), Selimiye Mosque in Edirne (1575), and Saint Peter's Cathedral in Rome (1626), the immediate examples that come to mind, are well-known structures with impressive domes.

In Ottoman architecture, dome is a focal point as a superstructure element in the public buildings such as mosque, madrasah, khan, and bath. In the Ottoman baths, which are the important public buildings, domes were used as the superstructure of square planned dressing hall, warm and hot spaces. Domes in Ottoman bath architecture provide dynamic mass feature with various numbers and sizes by juxtaposing to each other on the exterior. Light for the bathing spaces was provided with either terracotta pipes placed in the brick bonds or oculi formed by brick bond. These elements constituted spectacular and striking spatial features (Figs. 1 and 2).

Architectural characteristics [1-9], construction techniques $[2,6-8,10]$ and structural behavior of domes $[1,2,6-16]$ were previously investigated in a large number of published studies. Domes are the most damaged structural elements in historic masonry buildings. Therefore, knowledge of the construction techniques of domes and the characteristics of materials used in the dome construction is significant in terms of determining the properties of interventions applied in conservation works.

In this study, the relationship between bond type, dome span, dome height, dome thickness, and the number of oculi of domes in some Ottoman baths in Western Anatolia were investigated 


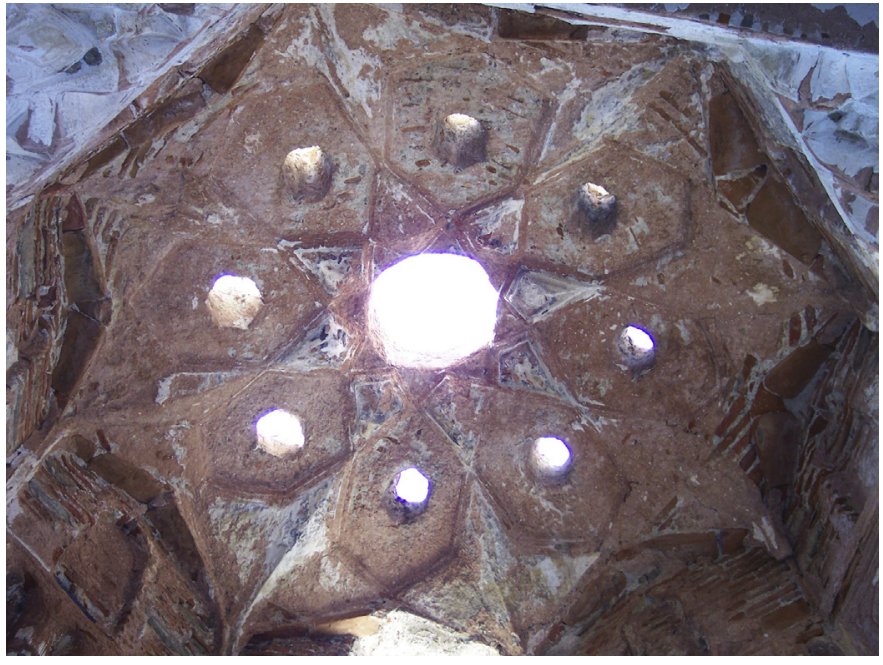

Fig. 1. The interior view of Tahtakale Bath iwan dome, hexagonal oculi in overlapping geometric pattern.

for their architectural characteristics and construction techniques which need to be preserved.

\section{Studied baths}

In the study, Ottoman baths which were located in Urla, Seferihisar and Tire near İzmir in Western Anatolia were examined (Fig. 3). These are Hersekzade Ahmet Paşa Bath (Double Bath), Rüstem Paşa Bath, Kamanlı Bath (Yahşi Bey), and Özbek Village Bath in Urla; Seferihisar Büyük and Küçük Baths, Sığacık Kaleiçi Bath, Düzce (Hereke) Bath, and Ulamış Bath in Seferihisar; Tahtakale Bath, Hekim Bath, Yalınayak Bath, Yeniceköy Bath, Şeyh Bath, Mehmet Ağa Bath, and Karagazi Bath in Tire. The baths date back to the 15 th and 16 th centuries according to their architectural features [17].

In the scope of the study, 79 domes of 16 baths were examined. In the examination of the construction techniques of the domes preliminary observations and free-hand sketch drawings were initially carried out and subsequently the field survey documentation was performed using conventional measured techniques supported by tachometric techniques using Topcon 7003i total station.

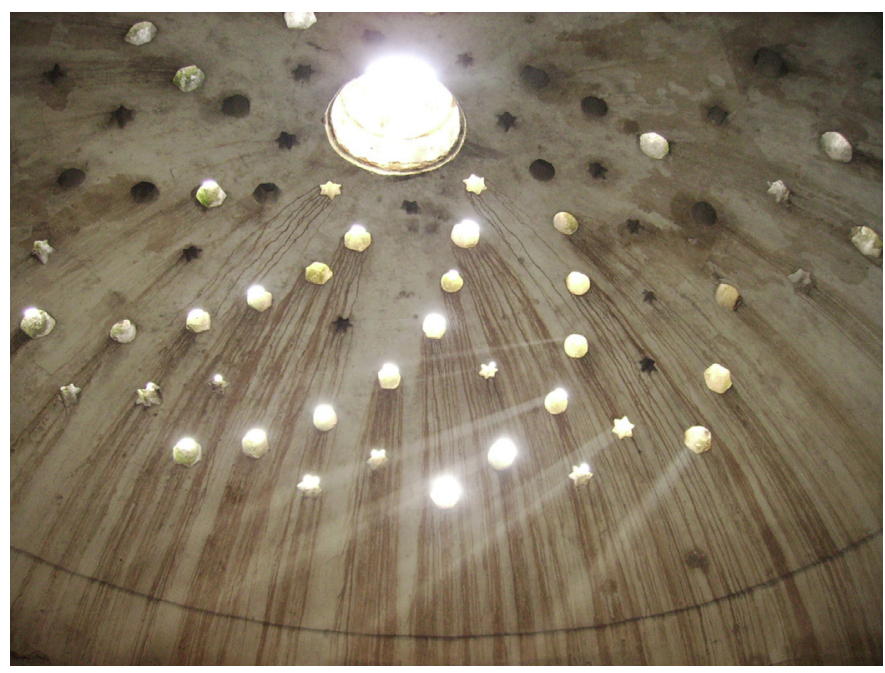

Fig. 2. The interior view of Yalınayak Bath hot main space dome, hexagonal oculi in spiral geometrical order with star shaped in between randomly.

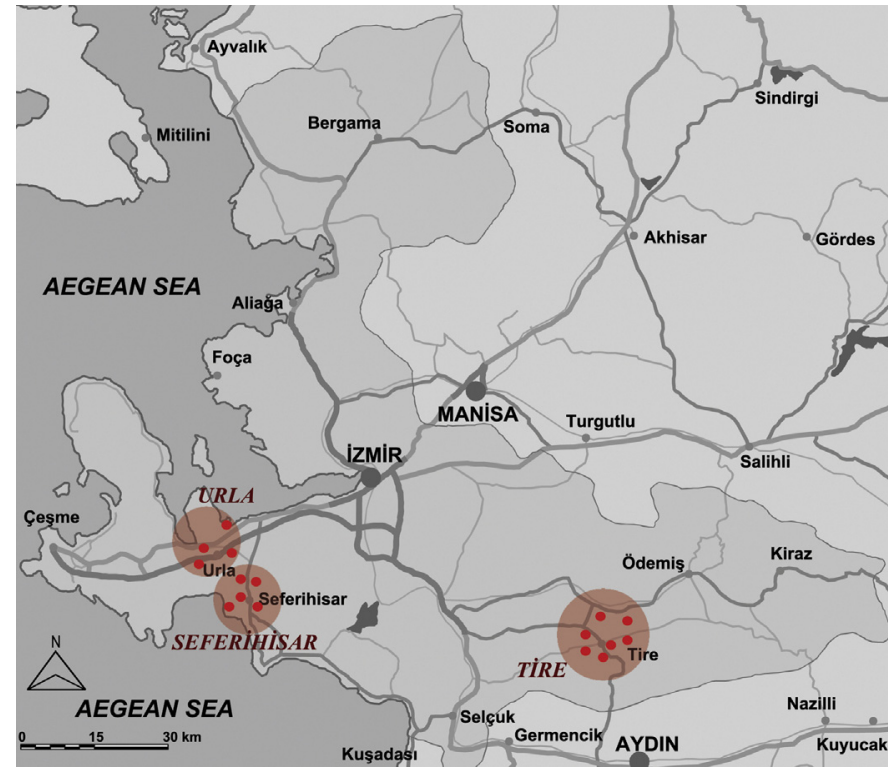

Fig. 3. The map of studied Ottoman baths located in Tire, Urla and Seferihisar towns near İzmir.

Obtained data were classified and evaluated in terms of the relationship between bond type, dome span, dome height, dome thickness, and the number of oculi.

\section{Material use and construction technique}

Studied domes can be defined as shell-type structures which can be modeled with uniform elements represented by bricks and mortar [18].

Material: The characteristics of bricks and mortar used in the construction of domes were investigated in previous researches and published. Bricks used in the dome constructions were manufactured by using calcium poor clays at low temperatures $\left(600-900^{\circ} \mathrm{C}\right)$. The bricks have low density and high porosity. Mortars used as binder in the brick bonds were produced by using pure lime and pozzolanic aggregates that have hydraulic features [18].

In the bonds of domes, both whole and half bricks were used. The whole brick sizes have two variations. The first is $39-40 \times 27-28 \times 4-4.5 \mathrm{~cm}$ in size; the other is $30-32 \times 21-24 \times 3-4.5 \mathrm{~cm}$ in size, while the half bricks are $21-24 \times 14-16 \times 3-4.5 \mathrm{~cm}$ in size. The dimensions of joints are between 1.5 and $2.5 \mathrm{~cm}$ in width on the interior surfaces while between 3 and $5 \mathrm{~cm}$ in width on the exterior surfaces and the joints are flush. The interior and exterior surfaces of domes were coated with brick-lime plaster.

The thickness of brick-lime plaster is $1-1.5 \mathrm{~cm}$ as a single layer mixed with brick powder on the interior surfaces, while $3-11 \mathrm{~cm}$ as two layers (the first layer of $2-8 \mathrm{~cm}$ mixed with small and large brick pieces, the upper layer of $1-3 \mathrm{~cm}$ mixed with brick powder) on the exterior surfaces (Figs. 4 and 5) [19].

Construction technique: The construction technique of domes has four different variations. The most common two techniques are as follows:

- Domes constructed with single whole brick/applied in the short span domes (0.95-3.45 m), (Fig. 4),

- Domes constructed with starting two whole bricks at the springing level, turning into one and a half brick at the upper side and ending single whole brick at the dome peak/applied in the mid and long span domes (3.5 $\mathrm{m}$ and above), (Fig. 5). 


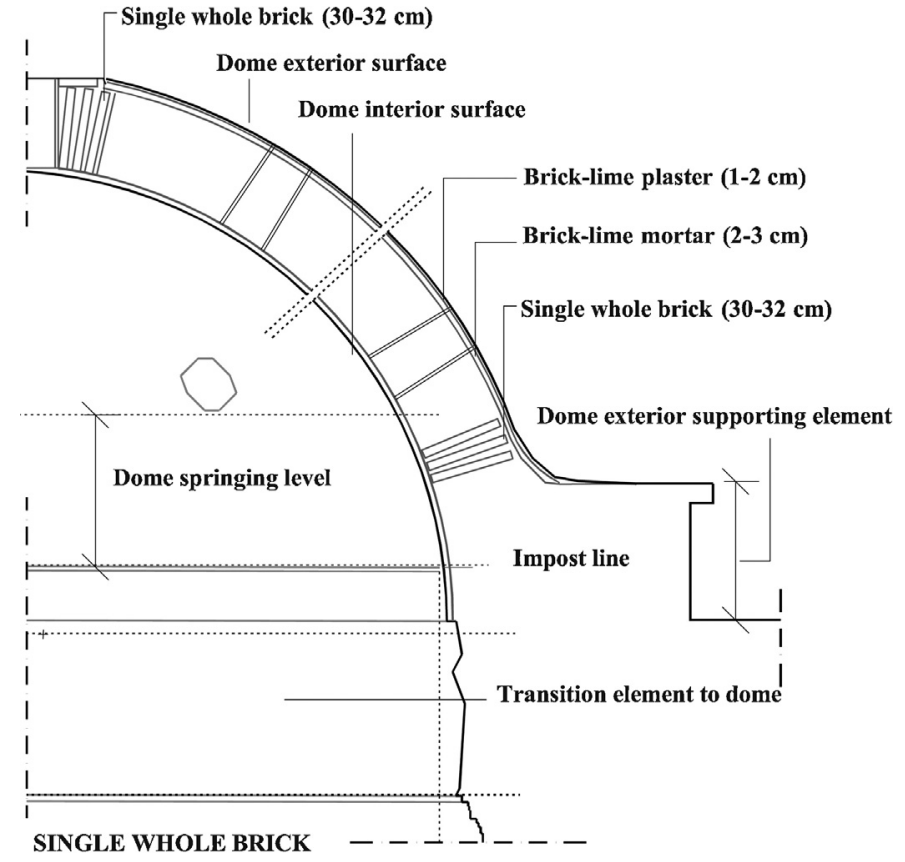

Fig. 4. Single whole brick in short span dome construction in span between $0.95-3.45 \mathrm{~m}$

Apart from these two common types, two more were determined:

- Domes constructed with single whole brick; starting with single whole brick and a thick brick-lime mortar $(10-15 \mathrm{~cm})$ at the springing level and ending as the same at the dome peak,

- Domes constructed with two whole bricks; starting with two whole bricks at the springing level and ending as the same at the dome peak.

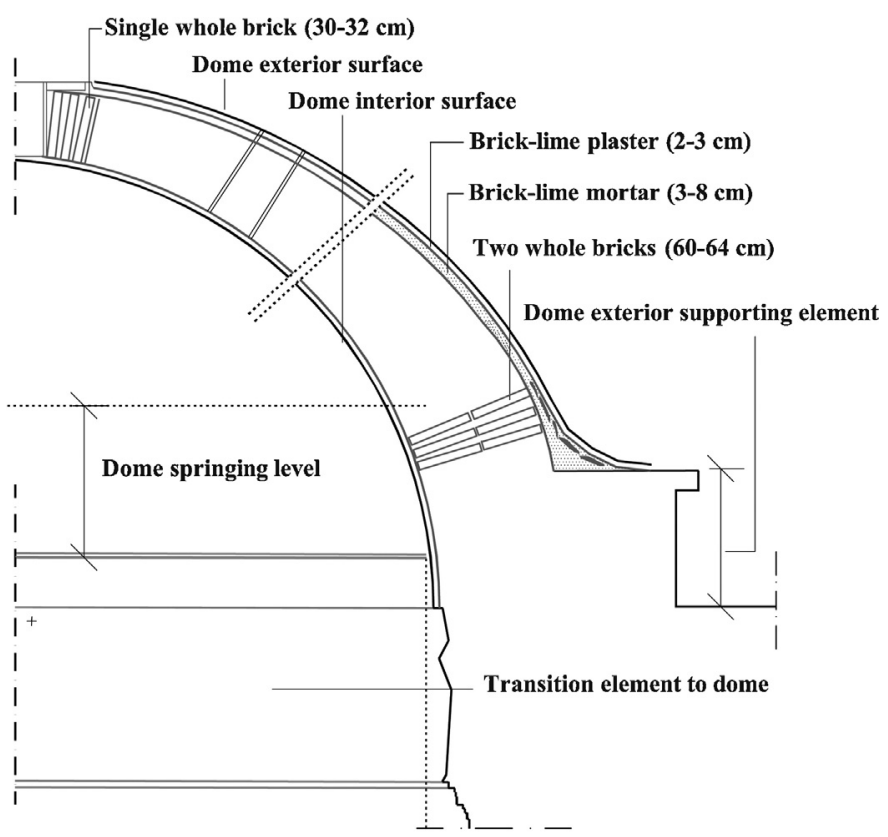

TRANSITION FROM TWO WHOLE BRICKS TO SINGLE WHOLE BRICK

Fig. 5. Transition from two whole bricks to single whole brick along thickness in mid and long span dome construction in span between $3.50-12.65 \mathrm{~m}$.
Bond type: In these construction techniques of domes, five different bond types were determined. These are;

(a) Horizontal stacking of the short faces in places non-parallel rows (in short span domes in span between $0.95-3.45 \mathrm{~m}$ ), (Fig. 6a),

(b) Horizontal and adjacent stacking of the short faces in parallel rows (in mid and long span domes in span $3.5 \mathrm{~m}$ and above), (Fig. 6b),

(c) Horizontal stacking of long faces on the bottom for a few rows and short faces on top in parallel rows (Fig. 6c),

(d) Random horizontal stacking of long and short faces (Fig. 6d),

(e) In vertical sequential stacking of long/short faces on interior, horizontal stacking of the long faces on exterior surface (Fig. $6 e)$.

The 'horizontal stacking of the short faces in places non-parallel rows' is observed as the most common application in short-span domes (39 domes). This bond type was mostly applied in the shortspan domes which were constructed with single whole brick. Dome thickness is about $35-40 \mathrm{~cm}$. The second common bond type of 'horizontal and adjacent stacking of the short faces in parallel rows' is observed in mid and long span domes (14 domes). This second common bond type was mostly applied in the mid and long span domes constructed with the technique of starting two whole bricks at the springing level, turning into one and a half brick at the upper and ending single whole brick at the dome peak. The oculi pierced in the domes were formed by using both half bricks and large brick pieces in the bond.

The 'horizontal stacking of the short faces in places non-parallel rows' bond type was constructed with the principle of non-parallel placement of the bricks in places with their short sides facing both inside and outside, with radial axes towards the center (Fig. 6a). In this bond type, joints have different thicknesses $(1.5-5 \mathrm{~cm})$ and stacking is non-parallel in some parts. Due to staggering one half of a brick, one-fourth or one-eighth length in random for each radial brick row on top of each other, joints that continue along the curvature of the domes were irregularly staggered. Horizontal/bed flush joints are in different thickness on the exterior $(1.5-5 \mathrm{~cm})$ due to non-parallel placement of the bricks in places while they are thin joints on the interior $(1-2.5 \mathrm{~cm})$. On the other hand, vertical/rising flush joints are in the same thickness on the interior and exterior and they are all thin joints $(1-2.5 \mathrm{~cm})$.

The 'horizontal and adjacent stacking of the short faces in parallel rows' bond type was constructed with radial and adjacent stacking of bricks in parallel courses. Due to staggering one half of a brick length for each radial brick row on top of each other, joints that continue along the curvature of the domes were regularly staggered (Fig. 6b). Horizontal flush joints are in the same thickness on all interior surfaces and at the springing level of the exterior surfaces and they are thin $(1-2.5 \mathrm{~cm})$; whereas, the width of horizontal flush joints on the exterior is gradually widening due to stacking of bricks in radial towards the peak of the dome and reached brick thickness (about $5 \mathrm{~cm}$ ). Vertical flush joints are in the same on the exterior and interior surfaces and they are thin $(1-2.5 \mathrm{~cm})$

\section{The relationship between span/height/thickness/the number of oculi}

To understand the construction techniques of domes, it is essential to examine the relationship between span, height, thickness and the number of oculi. The linear relationship between span and height in the common first and second bond types of domes were noted. In the first bond type, the height-span ratio is nearly 0.48 


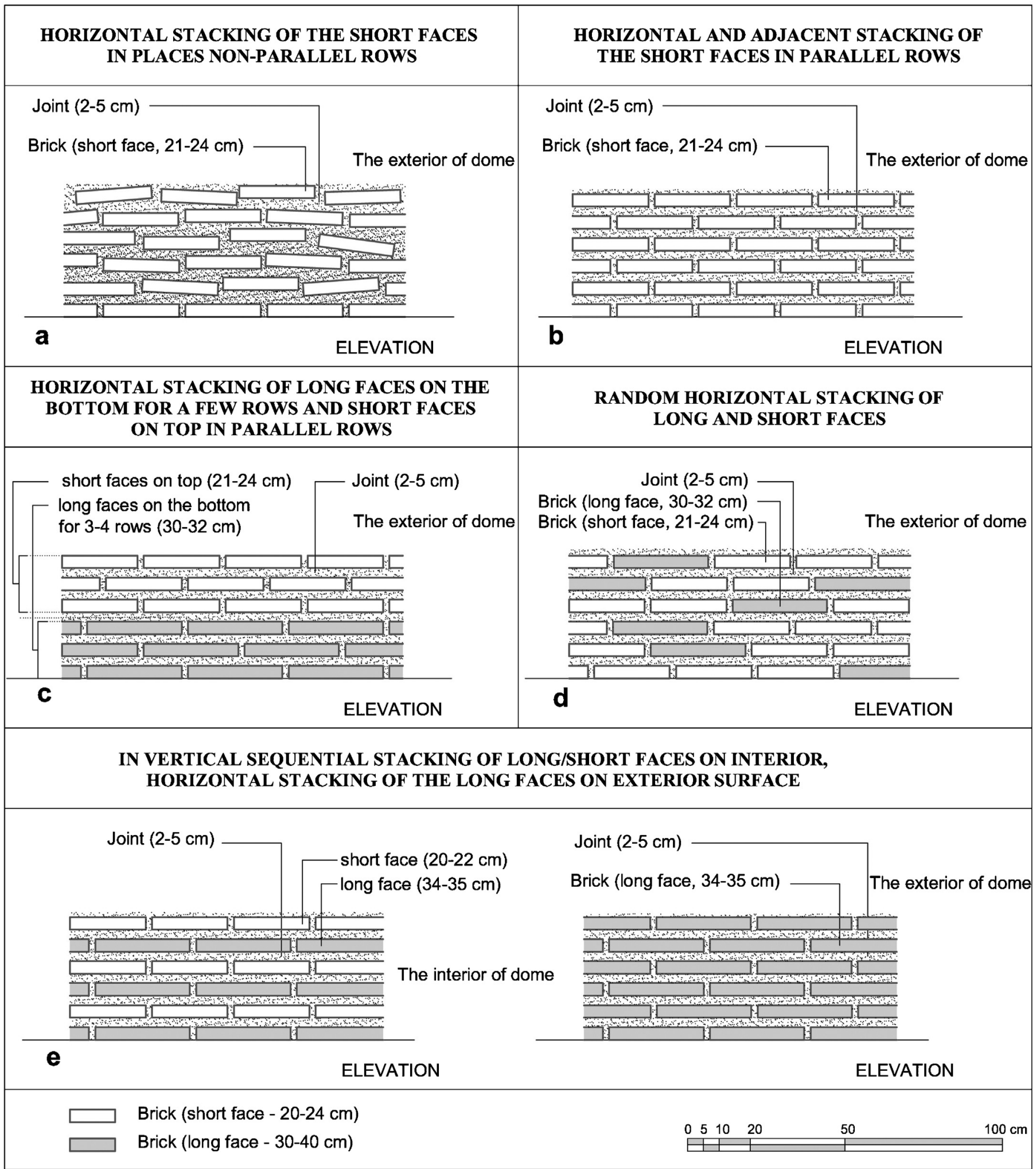

Fig. 6. Brick bond types in regular circular rows in the examined domes.

and in the second one is 0.4 (Fig. 7). Accordingly, long span domes have depressed profiles while short span domes have near semicircular profiles. The ratio detected between dome span and dome height was determined as $0.30-0.38$ in the domes constructed by Mimar Sinan [15].

Dome thickness is related to dome span. Dome peaks are in the thickness of single whole brick $(35-50 \mathrm{~cm})$. The thickness in short span domes $(0.95-3.45 \mathrm{~m})$ is in single whole brick dimension. In the mid span (3.5-6 m) and long span domes (6 $\mathrm{m}$ and above), thicknesses vary in the dome curvilinear according to dome span. The thickness, starting with two whole bricks $(65-75 \mathrm{~cm})$ at the springing level, which is the tension zone, is proceeding with one and a half brick at the upper side and turning into single whole brick at the dome peak. 
Table 1

Span, height, thickness, the dimension and number of oculi in domes of Ottoman baths.

\begin{tabular}{|c|c|c|c|c|c|c|c|}
\hline \multirow[t]{2}{*}{ Domes } & \multirow[t]{2}{*}{ Number } & \multirow[t]{2}{*}{ Span (m) } & \multirow[t]{2}{*}{ Height $(\mathrm{m})$} & \multirow[t]{2}{*}{ Thickness (m) } & \multicolumn{2}{|c|}{ Oculi dimensions $(\mathrm{cm})$} & \multirow[t]{2}{*}{ Oculi (number) } \\
\hline & & & & & Exterior & Interior & \\
\hline Short-span & 45 & $0.95-3.45$ & $0.58-2.01$ & $0.35-0.45$ & $12-15$ & $15-19$ & $5-23$ \\
\hline Mid-span & 27 & $3.5-6$ & $1.10-2.81$ & $0.45-0.65$ & $15-19$ & $20-24$ & $24-52$ \\
\hline Long-span & 7 & $6.05-12.65$ & $3.15-5.10$ & $0.60-0.76$ & $19-25$ & $25-30$ & $53-72$ \\
\hline
\end{tabular}

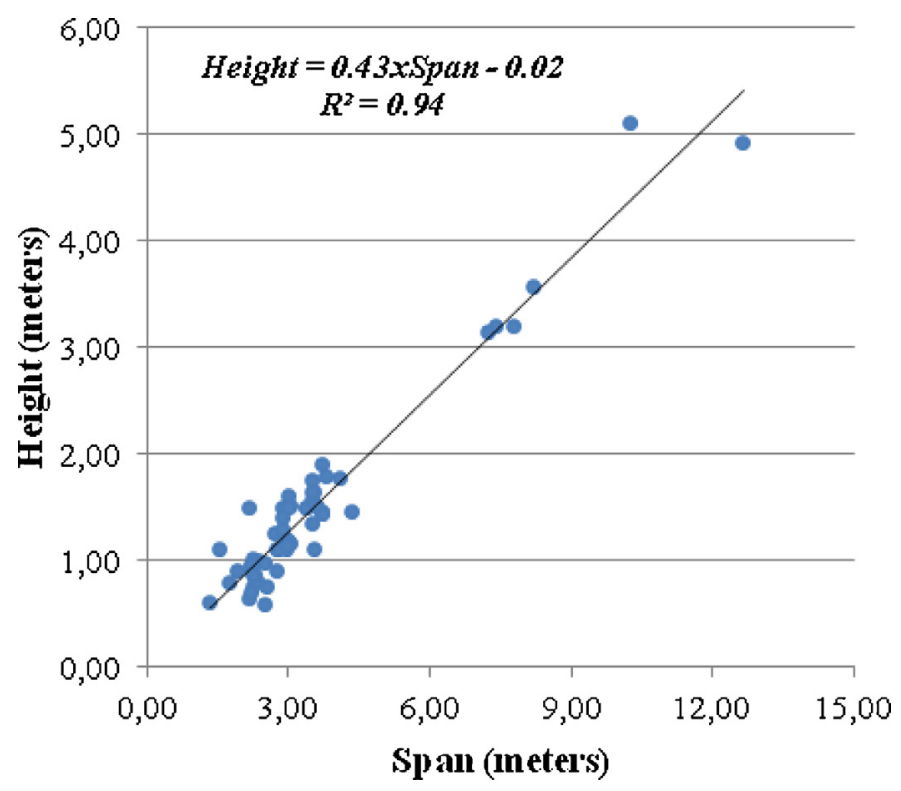

Fig. 7. The relationship between dome span and height.

In studied domes as the span increases, the thickness increases at the springing level. In the relationship between dome span and dome thickness at the springing level there is a ratio between 1:10 and 1:12. This ratio can also be determined in the domes of Haseki Hürrem Sultan Bath and Üsküdar Mihrimah, Kara Ahmet Paşa and Şehzade mosques in İstanbul, Tahtakale, Beylerbeyi and Topkapı Baths in Edirne, which were designed and built by Mimar Sinan.

Oculi, which were placed on curvilinear surfaces, are pentagonal, hexagonal, circular, or star shaped, generally in two or three

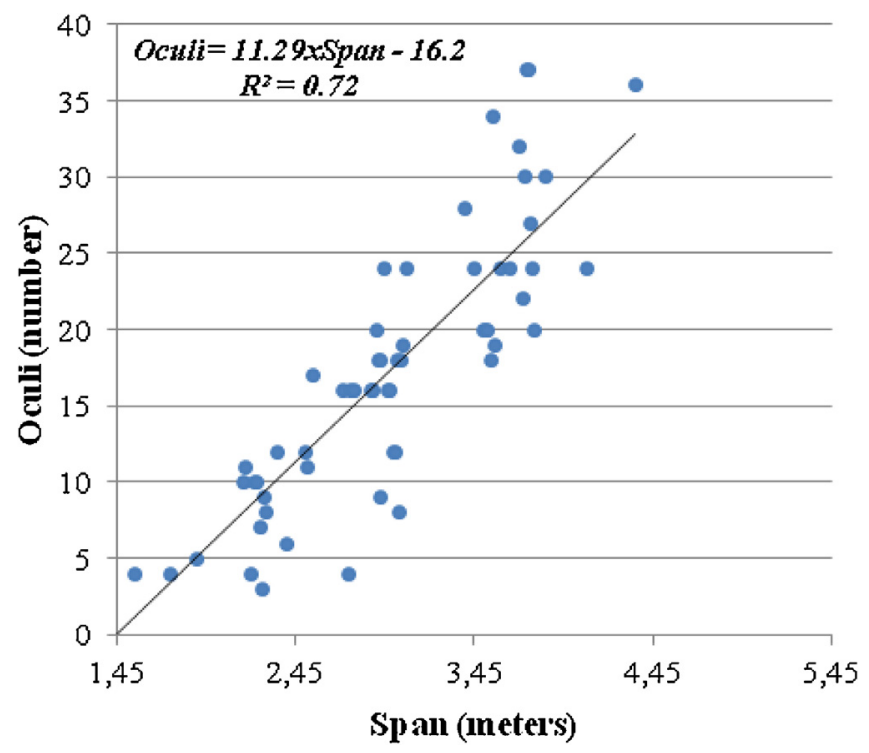

Fig. 8. The relationship between dome span and oculi number.

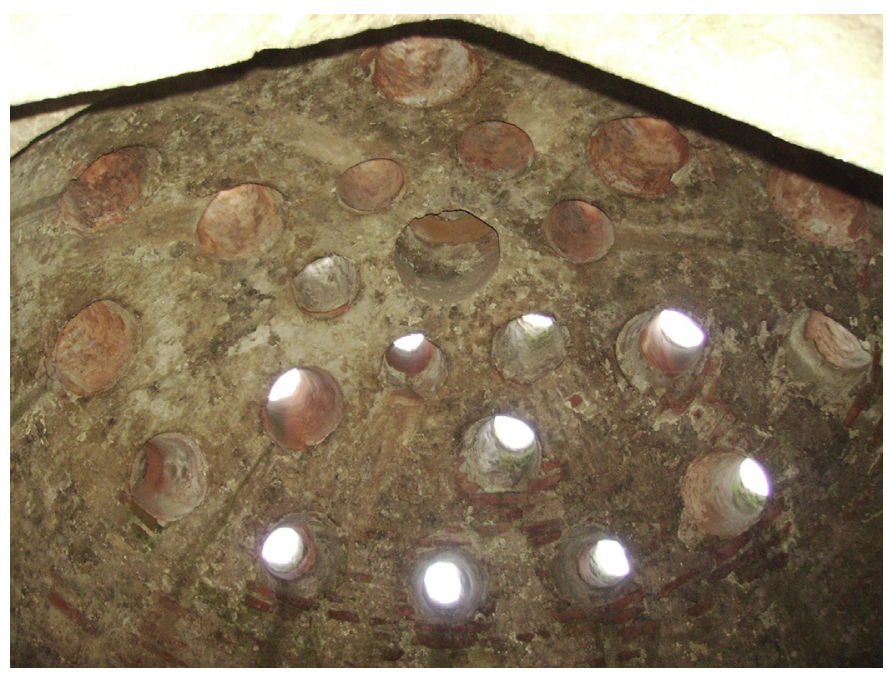

Fig. 9. Tire Hekim Bath men's section southeast hot room dome, use of terracotta pipes in the brick bond.

circular rows, and in decreasing number towards the dome peak. The domes with oculi commonly have spans between 2 and $4.5 \mathrm{~m}$. The number of oculi increases as the span increases. In a dome with $2 \mathrm{~m}$ span, defined maximum oculi number was detected as 5 . In a dome with $5 \mathrm{~m}$ span, defined maximum oculi number was detected as 48 (Fig. 8).

The width of the oculi has variable dimensions of between 15 and $30 \mathrm{~cm}$ on the interior depending on the dome span in narrowing sizes between 3 and $5 \mathrm{~cm}$ from interior to exterior (Table 1). The widths of oculi are commonly determined as consistent through the dome surface up to the top point. The circular oculi were formed through the terracotta pipes placed among the brick bond (Fig. 9).

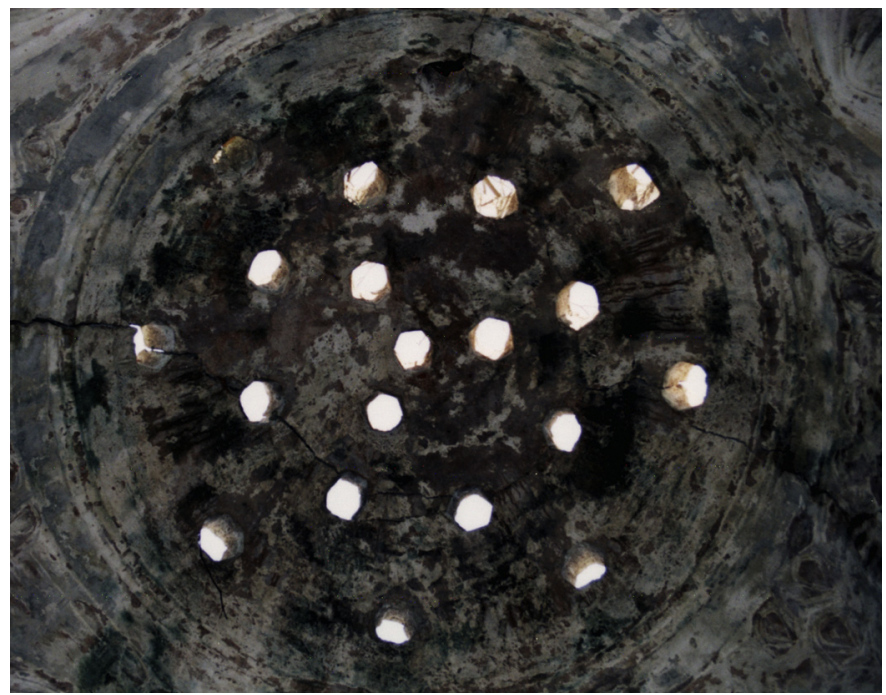

Fig. 10. The east hot room dome of Urla Kamanlı Bath, use of hexagonal shaped oculi formed by brick bond in circular three rows. 
On the other hand, pentagonal, hexagonal or star shaped oculi were formed by brick bond (Fig. 10). The openings were created using half bricks and large brick pieces and finished with brick-lime plaster.

\section{Conclusion}

The bath domes that were studied can be defined as shell-type structures that were constructed of bricks and mortar as binder. The result of this study having the objective of understanding the construction techniques of domes are summarized as follows:

- Long span domes have depressed profiles while short span domes have semi-circular profiles.

- The thickness in short span domes is in single whole brick dimension. In the mid span and long span domes, the thickness, starting with two whole bricks at the springing level, is proceeding with one and a half brick at the upper side and turning into single whole brick at the dome peak. Accordingly, the thickness has a dimension of single whole brick at the dome peaks of all domes.

- The springing level thickness of domes is about 1:10 of dome span.

- In short-span domes, the bond type of 'horizontal stacking of the short faces in places non-parallel rows' was used; whereas in the long span domes, the bond type of 'horizontal and adjacent stacking of the short faces in parallel rows' was applied.

- As the span increases, the number of oculi increases and the accumulated oculi are contributing to spatial aesthetics by providing light and shadow effects.

The baths examined in the scope of the study have survived until today keeping their original architectural and structural characteristics for almost 500 years. However, due to lack of care and maintenance and their exposure to atmospheric conditions, they need conservation interventions. The characteristics of the construction techniques of the studied domes should be preserved by future conservation works so as not to be lost. Care should be taken in the conservation interventions to sustain the original construction techniques and to use construction materials that are compatible with the original ones.

\section{References}

[1] H. Hager, Die kuppel des domes in Montefiascone. $\mathrm{Zu}$ einem borrominesken experiment von Carlo Fontana, Römisches Jahrbuch für Kunstgeschichte 15 (1975) 144-168.

[2] H.J. Cowan, The master builders: A history of structural and environmental design from ancient Egypt to the nineteenth century, John Willey \& Sons, New York, 1977
[3] M. Yorulmaz, Z. Ahunbay, Sinan camilerinde taşıyıcı sistem ve yapım teknikleri, Proceedings of II. International Congress on the History of Turkish and Islamic Science and Technology, İstanbul, Turkey, 28 April-2 May 1986, I.T.U Research Center of History of Science and Technology, İstanbul, 1987, pp. 123-143.

[4] S. Huerta Fernández, R. Aroca Hernández-Ros, Masonry Domes, A study on proportion and similarity, in: Proceedings of IASS 30th Anniversary World Congress, Vol 1, Madrid, Spain, 11-15 September 1989, Cedex - Laboratorio Central de Estructuras y Materiales, Madrid, 1989.

[5] R. Mark (Ed.), Architectural technology up to the scientific revolution: The art and structure of large-scale buildings, MIT, Press, Cambridge-London, England 1993.

[6] S. Huerta, Oval domes: History, geometry and mechanics, Nexus Networks Journal 9 (2) (2007) 211-248.

[7] F. Escrig, J.P. Varcarcel, Influence of constructive systems in the structural performance of ancient domes, in: C.A. Brebbia, B. Leftheris (Eds.), STREMAH' 95, Structural Studies, Repairs and Maintenance of Historical Buildings IV: Dynamics, Repairs and Restoration, Vol. 2, Crete, Greece, 22-24 May 1995 Computational Mechanics Publications, Southampton, UK, 1995, pp. 179-188.

[8] G. Croci, The conservation and Structural Restoration of Architectural Heritage, Computational Mechanics Publications, Southampton, UK, 1998.

[9] G. Lopez Manzanares, The XVIIth century: Carlo Fontana's expertises, in: S. Huerta (Ed.), Proceedings of the First International Congress on Construction History, 20-24 January 2003, Instituto Juan de Herrera, Escuela, Técnica Superior de Arquitectura, Madrid, 2003, pp. 1307-1320.

[10] B.M. Fielden, Conservation of historic Buildings; Structural Elements I: Beams, Arches Vaults and Domes, The Architectural Press, Oxford, UK, 2001, pp. 37-49.

[11] J. Heyman, On shell solutions of masonry domes, International Journal of Solids and Structures 3 (2) (1967) 227-241.

[12] I. Mungan, On the structural development of the Ottoman dome with emphasis on Sinan, Domes from Antiquity to the Present, Proceedings of the IASS-MSU International Symposium, İstanbul, Turkey, 30 May-3 June 1988, Mimar Sinan University, İstanbul, 1988, pp. 105-114.

[13] S. Huerta Fernández, Diseño estructural de arcos, bóvedas y cúpulas en España, ca. $1500 \sim$ ca. 1800, Ph.D. thesis, Universidad Politécnica de Madrid, Escuela Técnica Superior de Arquitectura, Madrid, 1990.

[14] D. D'Ayala, Analytical method for the assessment of the safety levels of domes, in: C.A. Brebbia, R.J.B. Frewer (Eds.), Third International Conference on Structural Studies, Repairs and Maintenance of Historical Buildings at Bath, England: Structural Repair and Maintenance of Historical Buildings III, 16-18 June 1993 Computational Mechanics Publications, Southampton and Boston, USA, 1993, pp. 347-355.

[15] N. Camlıbel, Sinan mimarlığında yapı strüktürünün analitik incelenmesi, Yıldız Teknik Üniversitesi Basım-Yayın Merkezi Matbaası, İstanbul, Turkey, 1998.

[16] V. Russo, G.P. Lignola, E. Cosenza, G. Tucci, Static history and structural assessment of masonry domes. The treasure of St. Gennaro's Chapel in Naples, in: P.B. Lourenço, P. Roca, C. Modena, S. Agrawal (Eds.), SAHC'2006 - Proceedings of the 5th International Conference on Structural Analysis of Historical Constructions, New Delhi, India, 6-8 November 2006, University of Minho, Department of Civil Engineering, Macmillan India Ltd., Guimarães, Portugal, 2006, pp. 1461-1468.

[17] K. Reyhan, Construction techniques and materials of the Ottoman period baths in Seferihisar-Urla region, M.Sc. thesis, İzmir Institute of Technology, İzmir 2004.

[18] E. Uğurlu Sağın, K. Reyhan, B. İpekoğlu, H. Böke, Investigation of construction techniques and material properties used in the domes of historical baths, in: Proceedings of WCCE-ECCE-TCCE Joint Conference 2 Seismic Protection of Cultural Heritage, Antalya, Turkey, 31 October-1 November 2011, Turkish Chamber of Civil Engineers, IMO, Publication, Ankara, 2011, pp. 249-259.

[19] K. Reyhan, Architectural characteristics and construction techniques of domes in a group of Ottoman baths, Ph.D. thesis, İzmir Institute of Technology, İzmir, 2011. 